some of the most difficult portions had to be super. intended by Stephenson himself. The work of the greatest magnitude was the construction of the Kilsby Tunnel south of Rugby, a costly undertaking rendered necessary through the short-sighted opposition of the inhabitants of Northampton to the proposal that the line should pass by way of that town.

\section{John Dalton}

Dalton was elected a fellow of the Royal Society in 1822, and received one of the Society's Royal Medals in 1826, the first year of award, but until May 1834, he had not attended to be formally admitted. Babbage was, at the time, actively interesting himself in Dalton's presentation at Court, duly effected, it may be mentioned, though he did not go clad in levée dress. The particular reason, however, for Dalton's stay in London was to give sittings to Chantrey, the sculptor, who had been commissioned by a representative committee to execute a statue of him. Dalton recorded his visit to Chantrey thus : " $\mathrm{He}$ [Chantrey] took a profile as large as life by a camera lucida, and then sketched a front view of the face on paper. He then gave me the next day for a holiday and told me I should see my head moulded in clay on Wednesday morning, at which time he invited me to breakfast. I went accordingly, and found, as he said, a head apparently perfect. $\mathrm{He}$ said he had not yet touched it, the head having been formed from his drawings by some of his assistants. He set to work to model and polish a little whilst I was mostly engaged in reading the newspaper, or conversing with him. On looking right and left he found my ears were not alike, and the modeller had made them alike, so that he immediately cut off the left ear of the bust and made a new one more resembling the original. At last he took a pitcher and blew a little water in my face (I mean the model), and covered my head with a wet cloth and we parted, he having desired me to bring Dr. Henry and Dr. Philip with me next morning to breakfast. We went accordingly and found an abundant table; soon after Dr. Faraday came in and we all went into the working room for a time. . . At intervals we have a little amusement and instruction about our respective arts and sciences, and how we acquired our knowledge, etc., in which we vie with each other".... (Henry, "Memoirs of John Dalton", 1854.)

Sir Henry Holland in his "Recollections" (p. 212) remarks, referring to Dalton's early years, that he "well knew that philosopher in his rude laboratory of bottles and uncouth apparatus at Manchesteran individuality in himself, apart from the Quaker garb he wore."

\section{Wernerian Natural History Society, Edinburgh}

In May 1834 the Society promoted and offered a number of honorary premiums, open unconditionally to all scientific workers. The terms were incorporated in a circular notice, from which three examples are quoted :-

(1) Twenty sovereigns, or a suitable piece of plate of that value for the best geological account, with a geognostical map, sections, and specimens, of the Three Lowthians, with as much of the neighbourhood as may be required for the elucidation of the districts. To be given in against December 1835 .

(2) Ten sovereigns, or a piece of plate for the best natural and economical history of the fishes, marine, fluviatile, and lacustrine of the river district of the Forth. To be given in against December 1835 .

(3) Ten sovereigns, or a piece of plate for the best account of the entomology of the Three Lothians, and river district of the Forth; with a collection of specimens, and map of the distribution of the insects. To be produced against December 1836. (Memoirs, vol. 7.)

\section{Societies and Academies}

\section{LONDON}

Physical Society, March 16. N. Thompson: The effective rotation temperature of the negative glow in nitrogen. The effective temperature increases slightly with the pressure and current strength, and to a much greater extent with the temperature of the furnace surrounding the discharge tube. At high temperatures it becomes less than the temperature of the furnace, and an explanation of this surprising behaviour is sought. It is concluded that, in this particular case at least, the effective temperature is not identical with the gas temperature, though it depends in part on that quantity. S. S. WATTS and B. J. Lloyd-Evans: The measurement of flametemperatures in a petrol engine by the spectral linereversal method. Until recently no satisfactory method existed for the measurement of the temperatures during combustion in a petrol engine. The reversal of a spectral line provides a suitable method which shows that the maximum temperature in the engine cylinder persists for a longer period than the maximum pressure. E. B. Moss : An apparatus for the determination of the dew point. The paper describes an optical system which uses diffraction by the dew droplets on a mirror and aids greatly the visual detection of dew-formation. Then follows an account of the application of this system to an automatic photoelectric apparatus for maintaining a mirror at the dew point.

\section{Dublin}

Royal Irish Academy, April 9. R. SouthenN : Food and growth of brown trout in Lough Derg and the River Shannon. The growth-rate and size of the trout is definitely correlated with the composition of the rocks in the drainage area. The water of Lough Derg and the Shannon is derived from lime. stone rocks and is alkaline; that of Lough Atorick comes from an area of Old Red. Sandstone and peat and is acid. The trout from Lough Derg and the River Shannon are large, quick-growing, have a relatively long life and mature late. Those from Lough Atorick are small, slow-growing, have a short life and mature at an early age. In the diet of the Lough Derg trout, 'mid-water' food, consisting of Cladocera of the plankton and perch fry, forms a considerable part, but the Lough Atorick trout do not utilise this abundant food and live to a large extent on terrestrial insects blown on to the water. The Shannon trout subsists almost entirely on bottom-living organisms.

\section{LEEDS}

Philosophical and Literary Society, March 6. A. Y. AMIN : Note on a property of Steinerian trihedra. H. Frazer : Subharmonic functions. The author generalises the various results he has given recently 
concerning subharmonic functions. R. WHIDDINGTON, E. G. Woodroofe and J. E. TAYLOR: Note on the excitation of the neon atom by electron impact. The changes of energy of the neon atom when bombarded by electrons of 120 volts are considered. Three transitions from the ground state $2^{1} S_{0}$ to the $3 s_{2}$, $3 p_{5}, 3 s^{\prime}{ }_{1}$ states are observed. The energy changes agree with those expected spectroscopically and the probabilities of the excitations are approximately in the ratio $16: 4: 5$. J. E. RoBERTs : Excitation of the nitrogen molecule by electron impact. A brief survey is made of the question of the excitation of diatomic molecules by electrons, from the normal to higher electronic states, and two problems arise : (a) the most probable energy loss of the exciting electron; and (b) the probability of excitation of vibrational levels near to the most probable levels. The case of the $X \rightarrow a$ transition in nitrogen is considered in detail. The best available potential energy curves are obtained using the known spectroscopic data and the Morse formula. Assuming harmonic vibration of the nuclei, the relative probabilities of excitation of a few of the vibration levels of the $a$ state are calculated. These are in good agreement with the experimental results of Brindley though the most probable energy loss found by Rudberg is somewhat higher. H. M. DAwson and W. Lowson: Velocity of the reaction between sodium chloroacetate and sodium hydroxide. Measurements at $25^{\circ}$ with the chloroacetate in considerable excess $\left(1 M . \mathrm{CH}_{2} \mathrm{Cl} . \mathrm{CO}_{2} \mathrm{Na}+0 \cdot 1 M \cdot \mathrm{NaOH}\right)$ show that the bimolecular velocity coefficient remains sensibly constant until about 70 per cent of the alkali has disappeared, but increases continuously in the later stages of the reaction. This increase appears to be due to the simultaneous occurrence of three other reactions in which the products of hydrolysis are formed as a result of the interaction of the chloroacetate ion with water molecules, other chloroacetate ions and glycollate ions respectively. W. CAMEroN WALKeR : A portrait of Joseph Priestley and some of its associations. E. MARJorie WraY : Structural changes in a woody twig after summer pruning. The basipetal development of the cambium and the dependence of radial growth upon the developing bud results in the isolation of any part of the stem left above the topmost bud, as a result of pruning, as a snag. This explains the pruning instruction always given, to prune immediately above a bud. The rapid drying of the snag is very unfavourable to meristematic activity and the only evidence of cambial activity in the snag is the formation of cork phellogen round the schlerenchyma and also just within the protoxylem. The healing of a well-pruned stem is so complete that in a year or two the cut is almost obliterated and thus entry of disease is prevented. Late summer pruning is followed almost immediately by the outgrowth of a single bud. This is attributed to the fact that at this time of the year, when the water-table in the tree is low and the air temperature is high, there is only sufficient water available to force one bud into growth.

\section{PARIS}

Academy of Sciences, March 26 (C.R., 198, 11931280). H. Lecompe : Notice on Dukinfield Henry Scott, Correspondant for the Section of Botany. J. Costantin, Magrou, Bouget and Mlle. V. Jaudel : The experimental production of mycorrhiza in the potato. Andre Blondex : Some remarks on the use of headlamps on motor-cars with a yellow beam.
Physiological reasons are given for the known favourable effects produced by the use of yellow glass with motor headlights in preventing dazzle. A. R. Crathorne : Moments of the binomial with respect to the origin. PAUL Levy : The $V$ and $W$ spaces. J. GERonImus : Some extremal properties of polynomials the total variation of which is given. KIng-LaI Hrong: The growth of integral functions of infinite order defined by a Taylor's series. Julius WoLFF : The integral of a holomorph function with real positive part in a demiplane is univalent. V. LALAN : An axiomatic definition of impulse and energy. EDmond Brun : The distribution of temperature in an insulating cylinder in rapid displacement in air. P. LeJAY and Lov Jou YU: The general characters of the intensity of gravity in the north-east of China. The value of $g$ diminishes as the distance west of the coast increases : the results are indicated on a chart. Georges VAUDET: The time of discharge of a battery of condensers in a metallic wire. The explosive volatilisation of a copper wire by the discharge has been studied by photography on a film with an interposed rotating mirror. The time varied from 14 to 36 microseconds according to the conditions of the experiment. N. THoN : The alternating current capacity of a nonpolarisable electrode. H. HuLuber and MLLe. Y. CAUchors: Weak lines in the $K \beta$ spectra of the elements 42 (molybdenum), 45 (rhodium) and 47 (silver). R. GurLLren: The absorption of liquid oxygen studied in great thicknesses. In these experiments the absorption spectra have been studied in thicknesses of liquid oxygen up to $109 \mathrm{~cm}$. The results are discussed in connexion with previous work (McLennan, Ellis and Kneser). Mrcher Kantzer : The absorbing properties of chromyl chloride. A list of lines in the absorption spectrum between the wave-lengths $5428 \mathrm{~A}$. and $5016 \mathrm{~A}$. A. ROUSSET : The molecular diffusion of light in liquids: the fluctuations of orientation of homopolar and heteropolar molecules. MLle. C. Chamú́ and M. HaïsSINSKY : The rôle of age and concentration of polonium of solutions in centrifugation experiments. The quantity of polonium precipitated on centrifuging (4,000 revs. per minute) increases with age: the amount diminishes as the concentration in polonium increases. L. HACKsPILL, A. P. RolLeT and LAUFFENBURGER : The double decomposition between ammonium nitrate and sodium chloride in the presence or absence of ammonia. The experimental results are given graphically on a Löwenherz diagram. A. DAMIENS: The expression of deliquescence and efflorescence. MLLE. BLANCHE GREDY and LÉON PraUX: The cis-trans isomerism and synionic isomerism in the case of the crotyl derivatives. $\mathbf{P}$. BraUMAN : Some organic compounds of vanadyl. Description of the preparation and properties of methyl vanadylsalicylate, methyl phenoxyvanadylsalicylate, vanadyl salicylate and vanadyl benzoate. Alexis Tchitchibabine : Phosphoric acid as a condensing agent. The alkylation of phenols and of their ether oxides. Georges Richard : Contribution to the study of the $\alpha$-chlorketones. EDMOND URION : A functional exchange between organo-magnesium compounds and halogen derivatives. Grignard has recently described a method of obtaining magnesium compounds the preparation of which is impossible by the ordinary methods; he ascribes the effects to the removal of a deposit from the surface of the magnesium. The author gives an alternative explanation which he regards as more probable. 
R. PAUL: A method of preparation of the $\alpha$-alkyltetrahydropyranes. RAYMOND FuroN: Preliminary observations on the existence at Damergou (Niger) of a Cretaceous fauna analogous with that of Djoua (South Algeria). HeNRy HUBERT: The circulation of atmospheric air at high altitudes above Madagascar. R. GAUTHERET : Researches on the reduction of silver nitrate by the chloroplasts. According to the author's experiments, the action of light is necessary to start this reaction. R. Echevin: The evolution of the phospholipids of leaves in the course of the autumnal change of colour. H. Courn and $J$. CARLES : Chemical affinities and hybridisation in the Iris. G. Malençon: New observations concerning the etiology of Bayoud (disease of the palm). $F$. DIÉNERT: Contribution to the study of occult condensations (hydrogenesis). J. LEGENDRE : Longevity in the larvæ of a tree-frequenting mosquito. A. Gruvel : Concerning some of the causes preventing the penetration of animal species into the Suez canal. Besides mechanical effects due to the direction of the tides at the entrance, the high salinity and drainage from oil refineries prevent the access of animal life to the canal. GaBriel BIDou: Protractor with index. An instrument for measuring the amplitude of movements of limbs. Raoul Lecoq: The possible existence, in proteins, of substances producing lack of food equilibrium. W. Kopaczewskr : The gelatinisation of serum by organic acids. Blood serum is rapidly converted into a transparent gel by the addition of lactic acid. Other organic acids can produce the same effect but less rapidly. C. LEvadiTr, MLle. R. Schoen and A. Vaisman: The mode of transmission and of propagation of the spirochætosis produced by Spirochceta muris and Spirochceta morsusmuris. J. Verge and H. LANCE : Swine influenza.

\section{VIENNA}

Academy of Sciences, February 1. Georg Koller and KARL PöPL: A lichen substance containing chlorine. This substance, which contains about 4 per cent of chlorine, appears to be chlorinated atranorin. Alois ZINkE and OTTo BenNDORF : Perylene and its derivatives (40). Franz HöLzL and Josef Krakora: Hexacyanoferro-acid and ethyl alcohol. Odomar GUGENBERGER: The Cardita strata of Launsdorf in Central Carinthia and their fauna: (3) Scaphopods and cephalopods. Lamellibranchs.

February 8. GeORG HornINGer : The granite of Schärding (Upper Austria). This granite resembles in appearance and structure the Mauthausen type, but is distinguished therefrom by the presence of large numbers of dark inclusions, frequently rich in biotite. GEORG BAIERSDORF : Experiments on the limiting proportions of cadmium and palladium detectable spectroscopically in silver. These proportions depend greatly, especially with cadmium, on the mode of excitation. J. D. Alfken, H. Bischoff, F. Maidl and St. Zimmermann : Hymenoptera (3). The occurrence of many species of insects on the islands of the Agean Archipelago is recorded. Pheidole teneriffana, Forel, previously met only in Northern Africa and Western Asia, is found on Milos. Anton Fuchs and Franz Kaüfel : Land and freshwater molluses from Greece and the islands of the Agean Sea. August GINzBERGer : The 'houses' of the larvæ of the cicada, Fidicina chlorogena Wlk. ARTUR WINKLER: Results of new [geological] studies in the middle and upper Isonzo region.

\section{Forthcoming Events}

[Meetings marked with an asterisk are open to the public.] Monday, May 28

Royal Geographical Society, at 8.30.-M. Conrad Kilian: "Exploratians Sohariennes" (in French).

\section{Tuesday, May 29}

Chadwick Public Lecture, at 5.30-(at the Royal United Service Institution, Whitehall, S.W.1).-Dr. J. B. Orr: "The National Food Supply and Public Health".*

\section{Wednesday, May 30}

Royal Society of Arts, at 4.30.-His Excellency Mirza Sayyed Hassan Khan Taqizadeh: "Modern Persia".

British ScIence Guild, at 9.30- (at the Royal Institution). Lord Rutherford: "Helium and other Rare Gases" (Research and Development Lecture).

\section{Thursday, May 31}

The Men of the Trees, at 5.30.-Sir E. Denison Ross : "Trees in Oriental Art and the Desiccation in the East".

Royal Aeronautical Society-(at the Science Museum, South Kensington, S.W.7).--Prof. B. Melvill Jones: Twenty-second Wilbur Wright Memorial Lecture.

Iron And Steel Instrtute, May 31-June 1.-Annual Meeting to be held at the Institution of Civil Engineers, Great George Street, Westminster, S.W.1.

Board of Greenkeeping Research, May 30.-Conference to be held at St. Ives Research Station. Sir John Russell : Chairman.

Prof. R. G. Stapledon: "The Age of Scientific Practice".

\section{Official Publications Received}

\section{Great Britain aNd Ireis}

The Carnegie United Kingdom Trust. Twentieth Annual Report, January-December 1933, approved by the Trustees at their Genera Meeting held on Friday, March 9th, 1934. Pp. vii $+94+9$ plates. (Dunfermline : Carnegie United Kingdom Trust.)

Ancient Monuments of Great Britain. List of Monuments prepared by the Commissioners of Works (to 31st December 1933) Pp. 82. (London: H.M. Stationery Office.) 18 . $3 d$. net.

The National Physical Laboratory. Report for the Year 1933. Pp. iv $+264+11$ plates. (London: H.M. Stationery Office.) 138. net. Stonyhurst Coilege Observatory. Results of Geophysical and Solar Observations, 1933; with Report and Notes of the Director, Rev. J. P. Rowland. Pp. xxiii +42. (Stonyhurst.)

\section{OTHER COUNTRIES}

Publications of the Dominion Observatory, Ottawa. Vol. 10: Bibliography of Seismology. No. 20: October, November, December 1933. By Ernest A. Hodgson. Pp. 339-368. (Ottawa : King's Printer.) 25 cents.

Proceedings of the Academy of Natural Sciences of Philadelphia, Vol. 86. Zoological Results of the Dolan West China Expedition o 1931, Part 2: Mollusks. By Henry A. Pilsbry. Pp. 5-28 +6 plates. Review of the Planorbidæ of Florida, with Notes on other Member of the Family. By Henry A. Pilsbry. Pp. 29-66 + plates 7-11. (Philadelphia.)

An Introduction to Social Insurance: Five Lectures delivered under the joint auspices of the University of the Witwatersrand, Johannesburg, and the Transvaal Workers' Educational Association. By Prof. John P. Daiton. Pp. viii + 116. (Johannesburg : University of the Witwatersrand Press.) 18

Carnegie Institute of Washington. Annual Report of the Director of the Department of Terrestrial Magnetism. (Reprinted from Year Book No. 32, for the Year 1932-33.) Pp. 211-266. (Washington, D.C. : Carnegie Institution.)

Straits Settlements. Annual Report of the Director of Gardens for the Year 1933. By R. E. Holttum. Pp. 8. (Singapore : Government Printing Office.) 1 dollar.

\section{Catalogues}

Catalogus van diverse Bibliotheken, verkooping 14-18 Mei 1934 Pp. 98. (Leiden: Burgersdijk and Niermans.)

Zeiss Nachrichten. Heft 6, April. Pp. 40. (Jena and London Carl Zeiss.)

Watson's Microscope Record. No. 32, May. Pp. 24. (London W. Watson and Sons, Ltd.)

Galvanometers, Photographic Recording Apparatus, Galvanometer Accessories. (Galvo 33.) Pp. 24. (Delft: P. J. Kipp en Zonen.) 